\title{
IMMUNOHISTOCHEMICAL EVALUATION OF p53 AND Ki-67 PROTEINS IN COLORECTAL ADENOMAS
}

\author{
Walysson Alves Tocantins de SOUSA, Lusmar Veras RODRIGUES, \\ Raimundo Gerônimo da SILVA Jr. and Fernando Lopes VIEIRA
}

\begin{abstract}
Context - The appearance of adenomas and their progression to adenocarcinomas is the result of an accumulation of genetic changes in cells of the intestinal mucosa inherited or acquired during life. Several proteins have been studied in relation to the development and progression of colorectal cancer, including tumor protein p53 (p53) and antigen identified by monoclonal antibody Ki-67 (Ki-67). Objective - To evaluate the expression of p53 and Ki-67 in colorectal adenomas and correlate the observed levels with clinical and pathologic findings. Method - The sample consisted of 50 adenomatous polyps from patients undergoing colonoscopy. After performing polypectomy, polyps were preserved in a formalin solution with 10\% (vol./vol.) phosphate buffer, submitted for routine preparation of sections and slides and stained with hematoxylin and eosin. For each adenoma we then performed immunohistochemistry to detect specific p53 and Ki-67 proteins using a streptavidin-biotin-peroxidase enzyme immunoassay. Results - p53 was detected in $18 \%$ of the adenomas. The average Ki-67 protein index (i.Ki-67) was 0.49 . A statistically significant difference was observed in p53 $(P=0.0003)$ and Ki-67 $(P=0.02)$ expression between adenomas with low- and high-grade dysplasia, particularly for $\mathrm{p} 53$. The expression of Ki-67 was greater in rectal adenomas than in colic adenomas $(P=0.02)$. No relationship was found between the expression of the two proteins in the sample. Conclusion - The p53 protein is expressed in a proportion of adenomas, while the Ki-67 protein was expressed in all adenomas. The expression of p53 was higher in adenomas with high-grade dysplasia. The expression of Ki-67 was higher in rectal adenomas and in adenomas with high-grade dysplasia.
\end{abstract}

HEADINGS - Colorectal neoplasm. Tumor suppressor protein p53. Ki67-antigen. Immunohistochemistry.

\section{INTRODUCTION}

Colorectal cancer is among the most frequent types of malignancy. In terms of incidence, it is the third most common cancer worldwide in both sexes $^{(7)}$. Among the key risk factors associated with the presence of adenomas is a factor closely linked to the development of malignant neoplasms. The chances of cure and survival are greater when detected at an early stage. Thus, the management of adenomas has an important role in the prevention of colorectal cancer, making it necessary to conduct studies to determine new prognostic factors related to development and progression.

The cell cycle is controlled by several genes, the main function of which is the synthesis of proteins that promote perfectly organized cell multiplication. These genes are basically divided into two groups: genes that stimulate cell proliferation, called protooncogenes, and genes that inhibit cell proliferation, called tumor suppressor genes ${ }^{(21,28)}$. The appearance of adenomas and their progression to adenocarcinomas is the result of an accumulation of genetic changes, in cells of the intestinal mucosa that have been inherited or acquired during life. Several proteins have been studied in relation to the development and progression of colorectal cancer, including tumor protein p53 (p53) and antigen identified by monoclonal antibody Ki-67 (Ki-67).

In humans, the p53 tumor suppressor gene is located on the locus of subdivision 13 of the short arm of chromosome 17 (17p13). Composed of 11 exons interspersed by 10 introns $^{(8,14)}$, it encodes a nuclear phosphoprotein - molecular mass equivalent to $53 \mathrm{kDa}$ - that contains a sequence of 393 amino acids $^{(13)}$. The main function of $\mathrm{p} 53$ is to mediate the cell response when DNA is damaged, assisting in the maintenance of genomic stability ${ }^{(26,33)}$. Mutation of the p53 gene (also known as TP53) promotes an accumulation of this protein in the cell nucleus and extends its half-life, making it detectable by immunohistochemistry $^{(6,19)}$ 
The expression of the Ki-67 protein in humans is closely associated with cell proliferation, and this is detected during the cell-cycle phases G1, S, G2 and mitosis, and absent in the G0 phase. Thus, Ki-67 is an excellent marker for proliferating cells ${ }^{(22)}$.

The aim of this study was to evaluate the expression of $\mathrm{p} 53$ and $\mathrm{Ki}-67$ in colorectal adenomas and correlate the observed levels with clinical and pathologic findings.

\section{METHODS}

The study was conducted at the Department of Coloproctology at Walter Cantídio University Hospital, Federal University of Ceará, Fortaleza, CE, Brazil and at the Digestive Endoscopy Service at Santa Maria Hospital in Teresina, PI, Brazil after having been approved by the local ethics committee (protocol 593/2009).

\section{Sample}

The sample consisted of 50 adenomas from 44 patients who underwent routine screening colonoscopy and were diagnosed with colorectal adenomatous polyps. Twentyfive adenomas were from 23 female patients and 25 from 21 male patients. The average age of the patients was 62.7 years (41-89 years).

\section{Inclusion criteria}

To be included in the study, individuals had to have histopathologic confirmation of colorectal adenoma.

\section{Exclusion criteria}

Patients with current or previous malignant neoplasms, intestinal polyposis, prior radiotherapy or inflammatory bowel disease were excluded.

\section{Endoscopy}

Patients underwent complete colonoscopy after mechanical preparation of the colon with a $10 \%$ (vol./vol.) mannitol solution. All examinations were performed by the same professional.

All polyps were resected using a diathermy loop and measured with the aid of a caliper. The polyps were preserved in a formalin solution with $10 \%$ (vol./vol.) phosphate buffer.

\section{Histopathology}

The material was sent to the pathology laboratory for macroscopic analysis and preparation for routine histological sectioning and staining with hematoxylin and eosin. The histological type and grade of dysplasia were subsequently determined ${ }^{(27)}$. All cases were evaluated independently by two pathologists for confirmation of histopathologic findings.

\section{Immunohistochemistry}

An immunohistochemical analysis was carried out to detect the expression of the $\mathrm{p} 53$ and $\mathrm{Ki}-67$ proteins, using a streptavidin-biotin immunoenzymic method. This included the following steps: (1) deparaffinization at $60^{\circ} \mathrm{C}(20 \mathrm{~min})$; (2) deparaffinization at room temperature (30 $\mathrm{min})$; (3) hydration with alcohol and water; (4) antigen retrieval: heating the slides in a solution of $0.01 \mathrm{~mol} / \mathrm{L}$ citric acid (pH 6.0) in a microwave oven (maximum power) for p53 (10 min), and in a pressure cooker for Ki-67 (5 min); (5) blockage of endogenous peroxidase in two baths of $3 \%$ (vol./vol.) $\mathrm{H}_{2} \mathrm{O}_{2}$ (10 min each) and rinsing with water and phosphate buffered saline (PBS); (6) incubation in a moist chamber at $4^{\circ} \mathrm{C}(18 \mathrm{~h})$ with monoclonal mouse antibodyspecific primary anti-human MIB-1 (Dako ${ }^{\circledR}$, Carpinteria, CA, USA) at a titration of 1:100 for Ki-67 and monoclonal mouse anti-human DO-7 (Dako ${ }^{\circledR}$, Carpinteria, CA, USA) at a titration of $1: 800$ for $\mathrm{p} 53$; (7) incubation with secondary biotinylated antibody(kit LSAB Dako ${ }^{\circledR}$, Carpinteria, CA, USA) in a moist chamber at $25^{\circ} \mathrm{C}(30 \mathrm{~min})$ followed by rinsing in PBS; (8) incubation with the streptavidin-biotin-peroxidase complex in a moist chamber $\left(37^{\circ} \mathrm{C}\right)$ for $30 \mathrm{~min}$ followed by rinsing in PBS; (9) disclosure by immersion in a solution of $60 \mathrm{mg} \%$ diaminobenzidine in PBS containing $0.06 \%$ (vol./ vol.) hydrogen peroxide followed by rinsing in distilled water; and (10) counterstaining in Harris hematoxylin, dehydration in alcohol and mounting in Entellan with coverslips. The positive nuclei present a typical brownish hue for each of the markers.

\section{Quantitative analysis of p53 and Ki-67}

The expression of p53 and Ki-67 was quantified with an automated system consisting of a Nikon light microscope coupled to a color video camera (Digital Camera Samsung SCC-131, Seoul, South Korea) with image acquisition by microcomputer (Pentium IV, 80 GB hard disk, 3.0 GHz processor, $1024 \mathrm{MB}$ RAM and graphics card for Windows $\mathrm{XP}^{\circledR}$ ).

Cell counts positive and negative for the expression of p53 and Ki-67 were performed under $\times 400$ magnification for the most intensely stained samples.

After scanning, 500 cells were counted in random fields of the mucosal epithelium using the image analysis program Image $\mathbf{J}^{\circledR}$. Fairly obvious dark-brown staining of cell nuclei was considered positive.

The calculation of the index of expression was performed using the following formula: $\mathrm{i}=$ (number of immunostained nuclei / number of nuclei counted).

Samples were considered positive for $\mathrm{p} 53$ when at least $10 \%$ of the cells presented this staining ${ }^{(10,17)}$. The cell proliferation index for Ki-67 (i.Ki-67) was calculated with the same formula and was expressed in absolute values.

\section{Statistical analysis}

The results were expressed as mean, standard deviation (SD), standard error (SE), minimum and maximum values for numerical variables and frequency for nominal variables.

Nominal variables were tested for statistical significance with Fisher's exact test. Numerical variables were submitted to Student's $t$ test or Pearson's linear correlation. The level of statistical significance was set at $P<0.05$. The statistics software Bioestat $5.0^{\circledR}$ was used for statistical analysis. 


\section{RESULTS}

\section{Location}

The polyps were distributed as follows: $15(30 \%)$ were located in the rectum and $35(70 \%)$ in the colon.

\section{Synchronous polyps}

Five patients had synchronous polyps with a total of 11 adenomas (Table 1). One patient had 3 adenomas. The remainder had 2 each.

\section{Macroscopic findings}

The size of the polyps ranged from $3 \mathrm{~mm}$ to $25 \mathrm{~mm}$ (average: $6.5 \pm 4.7 \mathrm{~mm})$. Polyps measured $<10 \mathrm{~mm}$ in 36 cases $(72 \%)$ and $\geq 10 \mathrm{~mm}$ in 14 cases $(28 \%)$ (Tables 1 and 2$)$.

\section{Microscopic findings}

With the exception of one case of tubulo-villous adenoma, all other cases were histologically classified as tubular adenoma. Regarding the degree of dysplasia, $33(66 \%)$ were classified as low grade and 17 (34\%) as high grade (Tables 1 and 2).

\section{Immunohistochemistry}

Nine specimens $(18 \%)$ were considered positive for p53 (Table 1). The average $( \pm \mathrm{SD})$ expression of Ki-67 was $0.49 \pm 0.17$ (Table 2).

Specimens positive for $\mathrm{p} 53$ came from patients aged $65.2 \pm 9.1$ years (range: $52-80$ years). The corresponding figures for p53-negative specimens were $62.2 \pm 10.9$ years (41-89 years) $(P=0.42)$ (Figure 1$)$.
The expression of $\mathrm{p} 53$ in relation to sex was positive in three men and six women $(P=0.46)$ (Table 1).

Polyps $<10 \mathrm{~mm}$ were $\mathrm{p} 53$-positive in five cases $(13.8 \%)$. Polyps $\geq 10 \mathrm{~mm}$ were p53-positive in four cases $(28.5 \%)$ $(P=0.41)$ (Table 1$)$.

As for location, two (13.3\%) of the polyps located in the rectum and seven $(20 \%)$ of the polyps located in the colon were positive for $\mathrm{p} 53(P=0.7)$ (Table 1$)$.

Concerning the degree of dysplasia, one out of 33 lowgrade specimens and eight out of 17 high-grade specimens were positive for p53 $(P=0.0003)$ (Table 1).

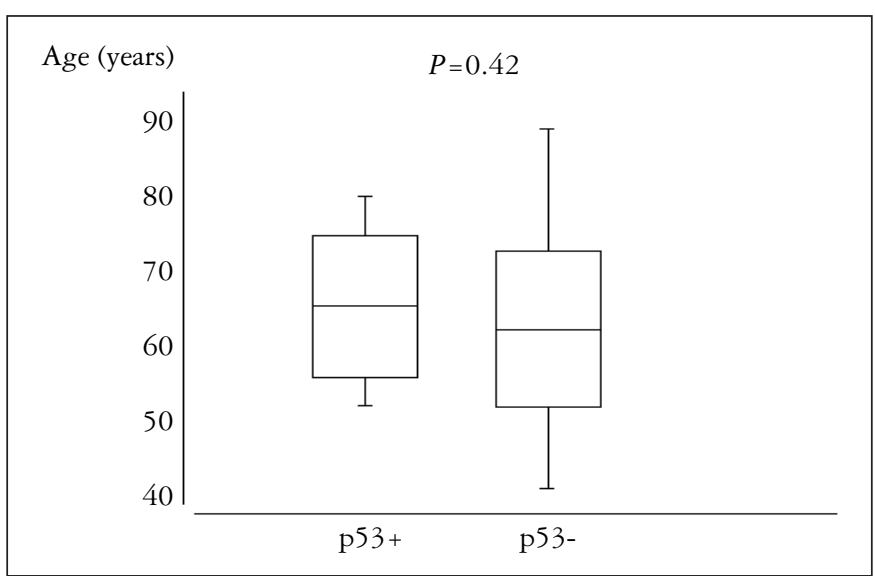

FIGURE 1. Box-plot of patients' age according to p53 protein expression

TABLE 1. Expression of $\mathrm{p} 53$ protein in adenomas

\begin{tabular}{|c|c|c|c|c|c|c|c|c|c|c|c|}
\hline & \multirow[t]{2}{*}{$\begin{array}{l}\text { Total } \\
\mathrm{n}(\%)\end{array}$} & \multicolumn{2}{|c|}{$\begin{array}{c}\text { Sex } \\
\mathrm{n}(\%)\end{array}$} & \multicolumn{2}{|c|}{$\begin{array}{c}\text { Site } \\
\mathrm{n}(\%)\end{array}$} & \multicolumn{2}{|c|}{$\begin{array}{l}\text { Size } \\
\mathrm{n}(\%)\end{array}$} & \multicolumn{2}{|c|}{$\begin{array}{c}\text { Dysplasia } \\
\mathrm{n}(\%)\end{array}$} & \multicolumn{2}{|c|}{$\begin{array}{c}\text { Synchronous polyp } \\
\mathrm{n}(\%)\end{array}$} \\
\hline & & Male & Female & Rectum & Colon & $<10 \mathrm{~mm}$ & $\geq 10 \mathrm{~mm}$ & Low & High $^{\mathrm{a}}$ & No & Yes \\
\hline $\mathrm{p} 53^{+}$ & $9(18)$ & $3(12)$ & $6(24)$ & $2(13.3)$ & $7(20)$ & $5(13.8)$ & $4(28.5)$ & $1(3)$ & $8(47)$ & $8(20.5)$ & $1(9)$ \\
\hline $\mathrm{p} 53^{-}$ & $41(82)$ & $22(88)$ & $19(76)$ & $13(86.7)$ & $28(80)$ & $31(86.2)$ & $10(71.5)$ & $32(97)$ & $9(53)$ & $31(79.5)$ & $10(91)$ \\
\hline Total & $50(100)$ & $25(100)$ & $25(100)$ & $15(100)$ & $35(100)$ & $36(100)$ & $14(100)$ & $33(100)$ & $17(100)$ & $39(100)$ & $11(100$ \\
\hline$P$-value & & \multicolumn{2}{|c|}{$P=0.46$} & \multicolumn{2}{|c|}{$P=0.7$} & $P=$ & 0.41 & \multicolumn{2}{|c|}{$P=0.0003$} & \multicolumn{2}{|c|}{$P=0.66$} \\
\hline
\end{tabular}

${ }^{a}$ The difference between two groups was statistically significant

TABLE 2. Expression of Ki-67 protein in adenomas

\begin{tabular}{|c|c|c|c|c|c|c|c|c|c|}
\hline Variable & & $\mathrm{n}$ & Mean & $\mathrm{SD}$ & $\mathrm{SE}$ & Minimum & Median & Maximum & $P$-value \\
\hline \multirow{2}{*}{ Sex } & Male & 25 & 0.51 & 0.19 & 0.04 & 0.24 & 0.44 & 0.95 & \multirow{2}{*}{$P=0.35$} \\
\hline & Female & 25 & 0.46 & 0.14 & 0.03 & 0.19 & 0.49 & 0.71 & \\
\hline \multirow{2}{*}{ Site } & Rectum $^{\mathrm{a}}$ & 15 & 0.57 & 0.19 & 0.05 & 0.28 & 0.61 & 0.95 & \multirow{2}{*}{$P=0.02$} \\
\hline & Colon & 35 & 0.45 & 0.15 & 0.02 & 0.19 & 0.42 & 0.9 & \\
\hline \multirow{2}{*}{ Size } & $<10 \mathrm{~mm}$ & 36 & 0.49 & 0.19 & 0.03 & 0.19 & 0.46 & 0.95 & \multirow{2}{*}{$P=0.7$} \\
\hline & $\geq 10 \mathrm{~mm}$ & 14 & 0.47 & 0.11 & 0.03 & 0.29 & 0.46 & 0.62 & \\
\hline \multirow{3}{*}{ Dysplasia } & Low & 33 & 0.45 & 0.16 & 0.02 & 0.19 & 0.41 & 0.85 & \multirow{3}{*}{$P=0.02$} \\
\hline & High $^{\mathrm{b}}$ & 17 & 0.56 & 0.17 & 0.04 & 0.29 & 0.56 & 0.95 & \\
\hline & Total & 50 & 0.49 & 0.17 & 0.02 & 0.19 & 0.46 & 0.95 & \\
\hline
\end{tabular}

a, $b$ The difference between the two groups was statistically significant 
As for synchronous polyps $(\mathrm{n}=11)$, one case was positive for $\mathrm{p} 53$. Eight of the 39 single polyps were $\mathrm{p} 53$ positive $(P=0.66)($ Table 1$)$.

When the association between $\mathrm{p} 53$ and Ki-67 expression was evaluated, i.Ki- 67 was $0.53 \pm 0.1$ for p53-positive polyps and $0.48 \pm 0.18$ for p53-negative polyps $(P=0.4)$ (Figure 2$)$.

Pearson's linear correlation was used to test the association between age and Ki-67 expression. The resulting coefficient was $r=-0.04(P=0.67)$ (Figure 3).

On average, $\mathrm{Ki}-67$ expression was $0.46 \pm 0.14$ in women and $0.51 \pm 0.19$ in men $(P=0.35)$ (Table 2).

With regard to size, Ki-67 expression was $0.49 \pm 0.19$ for polyps $<10 \mathrm{~mm}$ and $0.47 \pm 0.11$ for polyps $\geq 10 \mathrm{~mm}(P=0.7)$ (Table 2).

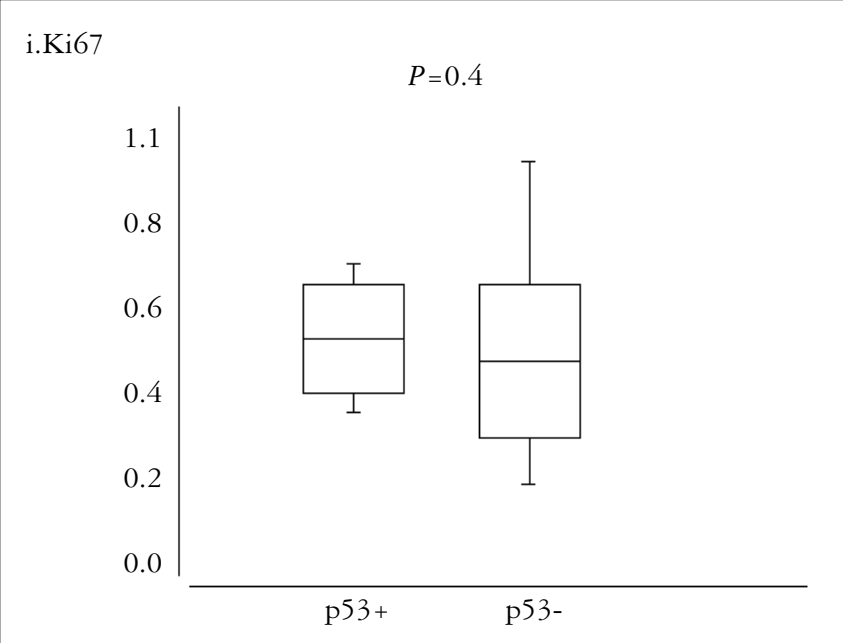

FIGURE 2. Box-plot of the expression of Ki-67 protein according to $\mathrm{p} 53$ protein expression

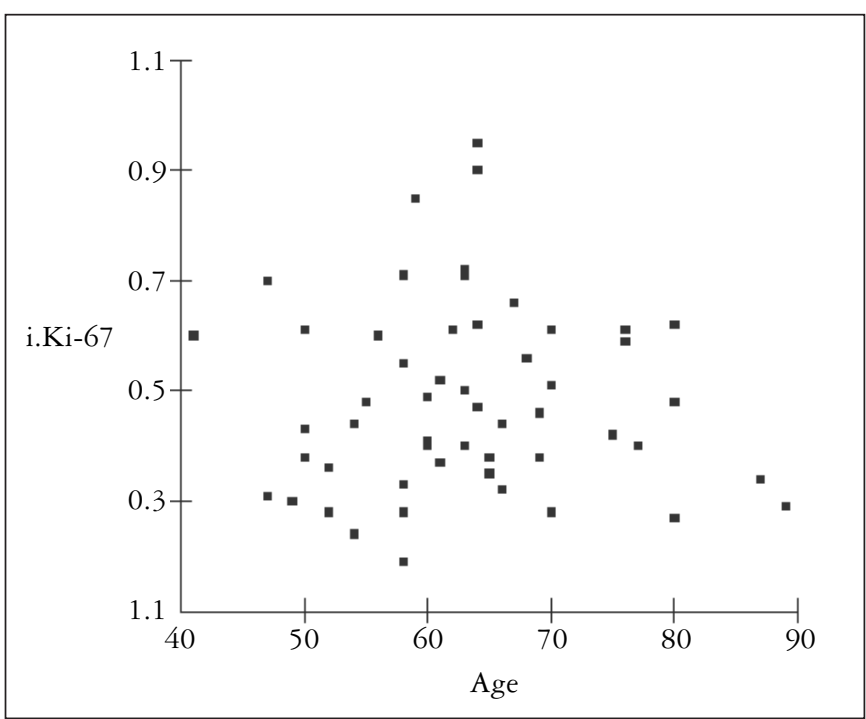

FIGURE 3. Scatter plot between age and i.Ki-67
Ki-67 expression was $0.57 \pm 0.19$ in rectal polyps and $0.45 \pm 0.15$ in colonic polyps $(P=0.02)$ (Table 2$)$.

Concerning the degree of dysplasia, the average Ki-67 expression index was $0.45 \pm 0.16$ for polyps with low-grade dysplasia and $0.56 \pm 0.17$ for polyps with high-grade dysplasia $(P=0.02)($ Table 2$)$.

\section{DISCUSSION}

Knowledge of factors associated with the genesis and progression of colorectal cancer is of great importance in the development of strategies for prevention and treatment. Polypectomy currently constitutes the best strategy for preventing colorectal cancer $^{(2)}$.

The identification of parameters reflecting the biological behavior of tumors, correlated with the severity and degree of evolution, is an important determinant of prognosis and improvement in cancer therapy. Despite recent progress in the study of the molecular mechanisms of cancer development and progression, few biological markers of prognostic value have been identified.

The 553 protein, sometimes referred to as the 'guardian of the genome', has been extensively researched in various types of cancers. Mutations are found in about $50 \%$ of all human cancers and more than 50 types of tumor ${ }^{(12)}$.

The association of the protein $\mathrm{Ki}-67$ is important when measuring cellular proliferative activity that may be exacerbated in neoplastic cells or in cells that have lost the ability to selfregulate. A high cell-proliferation index suggests a more aggressive behavior on part of the neoplasm and may have important prognostic implications ${ }^{(22)}$. The average age of the study population was 63 years and the sex distribution was fairly equal, matching findings in the literature showing the prevalence of polyps in patients aged $>50$ years, with no sex preference ${ }^{(9,11,18,32)}$. The data also support the claim that patients with adenomas and colorectal cancer have a similar age distribution (generally $>50$ years) ${ }^{(1,11,21)}$.

In our study, nine specimens tested positive for p53 (18\% of all cases). Watatani et al. ${ }^{(31)}$ analyzed the expression of p53 in adenomas and found variable rates of expression: initial adenomas, $12 \%$; synchronous adenomas with carcinomas, $20 \%$; metachronous adenoma after initial adenoma, $8 \%$; and metachronous adenoma after carcinoma, 30\%(27). Other authors have found positivity rates between $10 \%$ and $60 \%(3,17,24,30)$

The rate of p53 expression depends on the criteria used in the research method. In this study, only those cases in which the expression index was above $10 \%$ were considered positive. The choice of this cut-off point to classify the expression of $\mathrm{p} 53$ is owing to the fact that this figure shows the highest correlation between the immunohistochemical detection and mutation points of the $P 53$ gene $\mathrm{e}^{(5,23)}$.

The cellular levels of p53 are known to be very low under normal conditions because of the short half-life of the protein (5-45 min). Thus, detection by immunohistochemistry is not possible ${ }^{(6)}$. However, mutations in the P53 gene lead to the production of a p53 protein with greater stability and that may be detected immunohistochemically ${ }^{(19)}$. 
When relating the expression of $\mathrm{p} 53$ to clinical and pathologic characteristics (sex, age, location, size and degree of dysplasia), a statistically significant difference was found for the degree of polyp dysplasia, matching findings from earlier studies showing a positive relation between the degree of tumor dysplasia and immunohistochemical positivity for $\mathrm{p} 53^{(19,24,29,31)}$.

The relationship between $\mathrm{p} 53$ and the clinical and pathologic characteristics of adenomas is rarely explored in studies on this topic. In addition to a study by Vernillo et al. ${ }^{(29)}$ Voskuil et al. ${ }^{(30)}$ evaluated the immunohistochemical expression of $\mathrm{p} 53$ in sporadic adenomas and in adenomas from families with hereditary non-polyposis colorectal cancer (HNPCC). The study included intergroup (sporadic $x$ hereditary) and intragroup comparisons. Sporadic adenomas $>10 \mathrm{~mm}$ were associated with a higher frequency of p53 positivity. No other aspects, including the degree of dysplasia, were statistically significant.

Likewise, no relationship was found between the presence of synchronous adenomas and the detection of the $\mathrm{p} 53$ protein. The only p53-positive case of synchronous adenoma came from a patient with two adenomas, of which only one was positive. The factor responsible for such differences in positivity in the same patient remains unknown. The two adenomas also differed in size and degree of dysplasia: the p53-positive adenoma was $>10 \mathrm{~mm}$ and presented high-grade dysplasia.

Fearon and Vogelstein ${ }^{(4)}$ suggested a model for the evolution of colorectal tumors. The adenoma-to-carcinoma sequence is the result of an accumulation of genetic mutations that involve a different sequence: the mutation of the APC gene, DNA hypomethylation, activation of the K-ras protein, mutation of DCC (deleted in colorectal carcinoma) protein and, finally, mutation of the $\mathrm{p} 53$ protein. According to these authors, this last step is characteristic of carcinomas and rare in adenomas at any stage. In this study, $18 \%$ positivity in mutated p53 protein can not be regarded as unusual, although it is evident that the expression of p53 increases as the adenoma accumulates more dysplasia.

There was greater expression of Ki-67 protein in adenomas with high-grade dysplasia compared with low-grade dysplasia, matching results published by Radovanovic-Dinic et al. ${ }^{(20)}$.

The expression of Ki-67 was also higher in adenomas located in the rectum compared with the colon. To our knowledge, earlier studies contain no references to Ki-67 expression in relation to adenoma location. Thus, our results suggest that neoplastic cells in the rectal mucosa have a higher power of cell proliferation. This would explain the peculiar behavior of rectal cancer in relation to the location of colonic adenomas and also the higher frequency of malignancy in this segment of the large intestine.

As for the other parameters evaluated for the protein $\mathrm{Ki}$ 67 (sex, age and size), no significant differences were found. Similar results were reported by Vernillo et al. ${ }^{(29)}$. In another study, Radovanovic-Dinic et al. ${ }^{(20)}$ found a higher expression of $\mathrm{Ki}-67$ in adenomas of diameter larger than $10 \mathrm{~mm}$.

In fact, the proliferative activity of cells in the colorectal mucosa and throughout the gastrointestinal tract is constant, but increases under special circumstances, such as in inflammatory and neoplastic conditions ${ }^{(15,16,24,25)}$. In a study of patients with ulcerative colitis, Shinozaki et al. ${ }^{(25)}$ found a higher expression of Ki-67 in areas of dysplastic mucosa compared with areas without dysplasia. Muneyuki et al. ${ }^{(15)}$ conducted an evaluation of the expression of several proteins in tumors of the small intestine, in which i.Ki-67 was significantly higher in tumor areas than in areas of cancer-free mucosa. Sheikh et al. ${ }^{(24)}$ evaluated the expression of $\mathrm{Ki}-67$ in colorectal adenomas and observed an invariably stronger expression in areas with higher dysplasia. In a study on p53 and Ki-67 in gastrointestinal stromal tumors, Neves et al. ${ }^{(16)}$ found higher values of Ki-67 in patients with tumors of medium and high risk.

There was no statistically significant relationship between the expression of p53 and $\mathrm{Ki}-67$, in support of the results published by Vernillo et al. ${ }^{(29)}$ who found no association between p53 and Ki-67 in a group of 68 adenomas. The loss of function of p53 and its suppressive activity may have led to uncontrolled cellular activity with consequent accumulation of Ki-67, but further studies would be needed to confirm this association as most other studies in this area have assessed proteins individually rather than testing possible correlations between them. In addition, other factors and proteins act concurrently, either stimulating or suppressing cell proliferation.

The determination of more prognostic factors related to the development of colorectal cancer is of fundamental importance for primary prevention programs. Thus, the expression of p53 and Ki-67 may be useful as prognostic factors for adenomas in association with other known histopathologic features.

In conclusion, the $\mathrm{p} 53$ protein is expressed in a proportion of adenomas, while the $\mathrm{Ki}-67$ protein is expressed in all adenomas. There is greater expression of $\mathrm{p} 53$ in adenomas with high-grade dysplasia, while the expression of $\mathrm{Ki}-67$ is higher in rectal adenomas and adenomas with high-grade dysplasia. No other parameters correlated with protein expression. 
Sousa WAT, Rodrigues LV, Silva Jr RG, Vieira FL. Avaliação imunoistoquímica das proteínas p53 e Ki-67 em adenomas colorretais. Arq Gastroenterol. 2012;49(1):35-40.

RESUMO - Contexto - O aparecimento de adenomas intestinais e sua progressão para adenocarcinoma é o resultado do acúmulo de mutações genéticas da mucosa intestinal, herdadas ou adquiridas durante a vida. Dessa forma, várias proteínas têm sido estudadas em relação ao desenvolvimento e progressão do câncer colorretal, incluindo as proteínas p53 e Ki-67. Objetivo - Avaliar a expressão das proteínas p53 e Ki-67 em adenomas colorretais, suas relações com características clinicopatológicas e avaliar a relação entre as duas proteínas. Método - A amostra consistiu de 50 pólipos adenomatosos encontrados em pacientes submetidos a exames colonoscópicos. Após a realização de polipectomia, os pólipos eram conservados em solução tamponada de formalina a $10 \%$ e submetidos a rotina de preparo de cortes e lâminas e coloração pela hematoxilina-eosina para confirmação da natureza adenomatosa. Realizou-se imunoistoquímica específica para as proteínas p53 e Ki-67 pelo método imunoenzimático da streptoavidinabiotina-peroxidase para cada adenoma. Resultados - A proteína p53 foi positiva em $18 \%$ dos adenomas e a proteína Ki-67, expresso como índice (i.Ki-67), obteve média de 0,49. Houve diferença estatisticamente significante na expressão de p53 $(P=0,0003)$ e Ki-67( $P=0,02)$ entre os adenomas com alto e baixo grau de displasia, sendo maior no primeiro grupo. Encontrou-se, ainda maior expressão da proteína Ki-67 nos adenomas retais em relação aos de localização cólica $(P=0,02)$. Não houve relação entre a expressão das duas proteínas, na amostra. Conclusão - A proteína p53 é expressa em parte dos adenomas enquanto Ki-67 é expressa na sua totalidade. A expressão de p53 foi maior nos adenomas com alto grau de displasia. A expressão de Ki-67 foi maior nos adenomas retais e com alto grau de displasia.

DESCRITORES - Neoplasias colorretais. Proteína supressora de tumor p53. Antígeno Ki67. Imunoistoquímica.

\section{REFERENCES}

1. Brenner H, Hoffmeister M, Haug U. Should colorectal cancer screening start at same age in European countries? Contributions from descriptive epidemiology. Br J Cancer. 2008;99:532-5.

2. Citarda F, Tomaselli G, Capocaccia R, Barcherini S, Crespi M; Italian Multicenter Study Group. Efficacy in standard clinical pratice of colonoscopic polipectomy in reducing colorectal cancer incidence. Gut. 2001;48:812-5.

3. Enomoto T, Kuranami M, Kakita A. Variations in the expression of plateletderived endothelial cell growth factor in human colorectal polyps. Surg Today. 2000;30:711-7.

4. Fearon ER, Volgelstein B. A genetic model for colorectal tumorigenesis. Cell. 1990;61:759-67.

5. Grizzle WE, Myers RB, Manne U, Srivastava S. Immunohistochemical evaluation of biomarkers in prostatic and colorectal neoplasia. In: Hanausek M, Walaszek Z, editors. Methods in molecular medicine-tumor marker protocols. Totowa: Humana Press; 1998. p.143-60.

6. Horiuchi H, Kawamata H, Omotehara F, Fujii S, Fujimori T, Kuroda Y. Negative immunohistochemical staining of p53 protein does not always reflect wild-type p53 gene in cancer cells. J Gastroenterol. 2004;39:801-3.

7. Instituto Nacional do Câncer. Estimativa 2010 - Incidência de câncer no Brasil. Rio de Janeiro: INCA, 2010. Available at: http://www.inca.gov.br

8. Isobe M, Emmanuel BS, Givol D, Oren M, Crocen CM. Localization of gene for human p53 tumor antigen to band 17p13. Nature. 1986;320:84-5.

9. Loeve F, Boer R, Zauber AG, Van Ballegooijen M, Van Oortmarssen GJ, Winamer SJ, Habbema JD. National polyp study data: evidence for regression of adenomas. Int J cancer. 2004;111: 633-9.

10. Lustosa SA, Logullo A, Artigiani R, Saad SS, Goldenberg A, Matos D. Analysis of the correlation between $\mathrm{p} 53$ and bcl-2 expression with staging and prognosis of the colorectal adenocarcinoma. Acta Cir Bras. 2005;20:353-7.

11. Mansmann U, Crispin A, Henschel V, Adrion C, Augustin V, Birkner B, Munte A. Epidemiology and quality of control of 245000 outpatient colonoscopies. Dtsch Arztebl Int. 2008;105:434-40.

12. Matos LL, Machado LN, Sugiyama MM, Bozzetti RM, Pinhal AS. Technology applied to the detection of tumor markers. Arq Med ABC. 2005;30:19-25.

13. May P, May E. Twenty years of $\mathrm{p} 53$ research: structural and functions aspects of the protein. Oncogene. 1999;18:7621-738.

14. Miller C, Mohandas T, Wolf D, Prokocimer M, Rotter V, Koeffler HP Human p53 gene localized to short arm of chromosome 17. Nature. 1986;319:783-4.

15. Muneyuki T, Watanabe M, Yamanaka M, Isaji S, Kawarada Y, Yatani R. Combination analysis of genetic alterations and cell proliferation in small intestinal carcinomas. Dig Dis Sci. 2000;45:2022-8.

16. Neves LR, Oshima CT, Artingiani-Neto R, Yanaguibashi G, Lourenço LG, Forones NM. Ki67 and p53 in gastrointestinal stromal tumors-GIST. Arq Gastroenterol. 2009;46:116-20.

17. Nomura M, Watari J, Yokota K, Saitoh Y, Obara T, Kohgo Y. Morphogenesis of nonpolypoid colorectal adenomas and early carcinomas assessed by cell proliferation and apoptosis. Virchows Arch. 2000;437:17-24.
18. Petroianu A, Alberti LR, de Lima DC, Hauter HL, Rodrigues KC, Mendes JC. [Colonoscopic findings in asymptomatic people]. Arq Gastroenterol. 2009; $46: 173-8$

19. Porcelli B, Frosi B, Arezzini L, Marinello E, Vernillo R, De Martino A, Vatti R, Minacci C. Expression of p185 and p53 in benign and malignant colorectal lesions. Histochem J. 2001;33:51-7.

20. Radovanovic-Dinic B, Nagorni A, Katic V, Satmenkovic I, Zlatic A. An immunohistochemical study of Ki-67 in colorectal adenoma. Med Arh. 2009;63:16-8.

21. Santos Jr JCM. Ano-rectal-colic cancer. Current Issues II - Colorectal cancer Risk factors and prevention. Rev Bras Coloproctol. 2007;27:459-73.

22. Scholzen T, Gerdes J. The Ki-67 protein: from the known and the unknown. J Cell Physiol. 2000;182:311-22.

23. Shanmugam C, Katkoori VR, Jhala NC, Grizzle WE, Siegal GP, Manne U. p53 Nuclear accumulation and $\mathrm{Bcl}-2$ expression in contiguous adenomatous components of colorectal adenocarcinomas predict aggressive tumor behavior J Histochem cytochem. 2008;56:305-12.

24. Sheikh RA, Min BH, Yasmeen S, Teplitz R, Tesluk H, Ruebner BH, Tobi M, Hatfield J, Fligiel S, Lawson MJ. Correlation of Ki-67, p53, and Adnab-9 immunohistochemical staining and ploidy with clinical and histopathologic features of severely dysplastic colorectal adenomas. Dig Dis Sci. 2003;48:223-9.

25. Shinozaki M, Watanabe T, Kubota Y, Sawada T, Nagawa H, Muto T. High proliferative activity is associated with diysplasia in ulcerative colitis. Dis Colon Rectum. 2000;43:34-9.

26. Soussi T, Caron de Fromentel C, May P. Structural aspects of p53 protein in relation to gene evolution. Oncogene. 1990;5:5945-52.

27. Sugai T, Habano W, Uesugi N, Jiao Y, Nakamura S, Sato K, Chiba T, Ishii M. Molecular validation of the modified Vienna classification of colorectal tumors. J Mol Diagn. 2002;4:191-200.

28. Vermeulen K, Van Bockstaele DR, Berneman ZN. The cell cycle: a review of regulation, desregulation and therapeutic targets in cancer. Cell Prolif. 2003; 36:131-49.

29. Vernillo R, Lorenzi B, Banduccei T, Minacci C, Vindigni C, Lucenti Fei A, Lorenzi M. Immunohistochemical expression of p53 and ki67 in colorectal adenomas and prediction of malignancy and development of new polyps. Int J Biol Markers. 2008:23:89-95

30. Voskuil DW, Kampman E, van Geloof W, Grubben M, Kok F, Van Muijen G, Nagengast F, Vasen H, Van't Veer P. No major difference in K-ras and p53 abnormalities in sporadic and hereditary nonpolyposis colorectal adenomas. Dig Dis Sci. 2000;45:2187-94.

31. Watatani M, Ieda S, Kuroda K, Inui H, Nishimura K, Yasutomi M. Comparison of p53 and bcl-2 expression in initial, synchronous, and metachronous colorectal adenomas. Surg Today. 1999:29:707-12.

32. Williams AR, Balasooriya BA, Day DW. Polyps and cancer of the large bowel: a necropsy study in Liverpool. Gut. 1982;23:835-42.

33. Yonish-Rouach E. A question of lie or death: the p53 tumor suppressor gene Pathol Biol. 1997;45:815-23.

Received 1/6/2011 Accepted 23/8/2011. 